\title{
The Effect of Ferric Carboxymaltose Versus Iron Sucrose on Hemoglobin Levels in Pregnant Women with Anemia: Meta-Analysis
}

\author{
Astika Candra Nirwana', Yulia Lanti Retno Dewi²), Bhisma Murti1) \\ 1)Masters Program in Public Health, Universitas Sebelas Maret \\ 2)Faculty of Medicine, Universitas Sebelas Maret
}

\section{ABSTRACT}

Background: Anemia in pregnant women is one of the global health problems experienced by developed or developing countries affecting 1.62 billion world population, which corresponds to $24.8 \%$ of the population in the world. Anemia is a serious problem for maternal health because it is one of the five problems that becomes the target of solving the World Health Organization (WHO) in 2025. This study aimed to estimate the magnitude of the effect of Ferric Carboxymaltose on hemoglobin levels in pregnant women with anemia compared to Iron Sucrose.

Subjects and Method: This study was a metaanalysis study. The study was conducted by looking for data from the study results in the period 2010-2019. The data of this study was from Pubmed, DOAJ, Science Direct, Springer Link, Web of Science, Cochrane, Google Scholar, BMJ, BMC, Research Gate, J Stor, Wiley, Clinical Key, J Gate, SAGE, IEEE Xplore, ERIC Institute of Education Science, BASE, SciELO, WorldCat, Microsoft Academic, Index Copernicus, CABI, Cambridge, Nature, Oxford, ProQuest, and BJOG using the keyword "ferric carboxymaltose" AND "iron sucrose" AND "anemia in pregnancy" AND "randomized control trial" OR RCT, "ferric carboxymaltose" AND "iron sucrose" AND "hemoglobin in pregnancy" AND "randomized control trial". The subjects of this study were pregnant women with anemia. The study used a Revman 5.3 application to analyze the article.

Results: The eight articles were reviewed using the meta-analysis technique in this study. Pregnant women who were given ferric carboxymaltose therapy had a higher mean hemoglobin level than those who were not treated carboxymaltose therapy and it was statistically significant $(\mathrm{SMD}=1.11 ; 95 \% \mathrm{CI}=0.37$ to $1.85 ; \mathrm{p}=$ $0.003)$. The heterogeneity of the data showed $\mathrm{I}^{2}=$ $98 \%$ so that the distribution of the data was stated to be heterogeneous (random effect model).

Conclusion: Ferric Carboxymaltose is effective in increasing hemoglobin levels in pregnant women with anemia.

Keywords: Ferric Carboxymaltose, Iron Sucrose, Randomized Controlled Trial.

\section{Correspondence:}

Astika Candra Nirwana. Masters Program in Public Health, Universitas Sebelas Maret. Jl. Ir. Sutami 36A, Surakarta 57126, Central Java. Email: astikacandranirwana2796@gmail.com. Mobile: 085640018896.

\section{Cite this as:}

Nirwana AC, Dewi YLR, Murti B (2021). The Effect of Ferric Carboxymaltose Versus Iron Sucrose on Hemoglobin Levels in Pregnant Women with Anemia: Meta-Analysis. J Matern Child Health. 06(01): 15-27. https://doi.org/10.26911/thejmch.2021.06.01.02.

Journal of Maternal and Child Health is licensed under a Creative Commons Attribution-Non Commercial-Share Alike 4.0 International License.

\section{BACKGROUND}

Anemia is one of the global health problems experienced by developed and developing countries. Anemia affected 1.62 billion people in the world, which corresponded to $24.8 \%$ of the world's population (Pavord et al., 2012).
Anemia is a serious problem for maternal health because anemia is one of the five problems that becomes the target of solving the World Health Organization (WHO) in 2025. Anemia is also a risk factor that 
contributes to 50\% of maternal mortality (Khaskheli et al., 2016 ). WHO targets to reduce the incidence of anemia by $50 \%$ in women of childbearing age around the world.

A study conducted by Stevens et al. (2013) stated that globally from 1995 to 2011 in 107 countries, pregnant women had a high-risk factor for anemia cases. Anemia in pregnant women is a health problem that requires special attention due to the high incidence rates and complications that can arise in both mother and fetus (Obizue et al., 2013). Research continued to perform to assess the prevalence of anemia. Several studies stated that the prevalence of anemia in India, Indonesia, Ethiopia, and China still had high rates in pregnant women, which were $73.1 \%$, 37.1\%, 32.8\%, and 12.71\% (Gogoi et al., 2016 and Bekele et al., 2015).

The most common cause of anemia worldwide was iron deficiency anemia which was estimated to be about 50\% of the cases (Camaschella, 2015 and WHO, 2014).

Anemia is identified by low levels of hemoglobin and hematocrit in the blood. The lack of hemoglobin and hematocrit levels are caused by low production of red blood cells (erythrocytes), damage to erythrocytes (hemolysis), and loss of excessive blood. Pregnant women are the population that most susceptible to developing iron deficiency anemia. Health interventions had been carried out on a large scale, but the incidence of iron-deficiency anemia continued to increase in developing countries (Bilimale et al., 2010). Iron deficiency occurs when the amount of iron is not sufficient to meet the increasing body needs such as the condition of the mother during pregnancy, especially in the third trimester because it is used for fetal development (Tadesse et al., 2017).

A study conducted by Rahman et al., (2016) mentioned that anemia contributed to the incidence of LBW 25\%, preterm delivery
$44 \%$, and perinatal mortality $21 \%$ in lowincome countries. The effects of anemia suffered by mothers during pregnancy can increase the risk of malnourished infants.

According to WHO policy until 2025, anemia affects on nutritional deficiencies in infants, starting from the formation of the fetus, causing stunting and wasting.

The availability of Intravenous (IV) iron is quite promising, especially in severe anemia cases. Intravenous iron provides a greater and faster supply of iron than oral iron therapy without the gastrointestinal side effects from oral substitution and makes it possible to avoid blood transfusions with associated risks. To date, several studies had focused on the use of IV iron and its side effects and safety in pregnant women. Iron sucrose has been used for many years for the treatment of iron deficiency in pregnant women after the first trimester. However, the use of iron sucrose is limited to low doses because of local and systemic side effects at higher doses. Intravenous iron Ferric Carboxymaltose was then introduced in the scope of anemia management in the world of health.

Based on the route of administration, iron can be consumed by oral and intravenous (IV) injection. Intravenous iron is considered to be a useful option when prompt treatment is required (Qassim et al., 2017). Intravenous iron is considered to be a useful option when prompt treatment is required (Qassim et al., 2017). The fear of anaphylaxis (no formulation has the highest Food and Drug Administration or FDA safety level) the use of intravenous (IV) had no adverse side effects that had been reported for use in thousands of patients (Tolkien et al., 2015).

Based on the problems above, the researchers are interested in examining the effect of Ferric Carboxymaltose versus Iron Sucrose on hemoglobin levels in pregnant 
Nirwana et al./ The Effect of Ferric Carboxymaltose Versus Iron Sucrose on Hemoglobin Levels

women with anemia. The data obtained will be analyzed using meta-analysis.

\section{SUBJECTS AND METHOD}

\section{Study Design}

This study was a meta-analysis study. The study used data from the results of the previous studies in which the researcher presented the summary that corresponded the questions formulated by the researcher, namely the effect of Ferric Carboxymaltose. This study also used a systematic review which was useful in combining some results of the studies conducted separately and expected to reduce bias. Frequently, systematic reviews involved a meta-analysis process, namely statistical techniques to synthesize the data into one quantitative result to produce a measure of the effect summary (Lindsay, 2011).

\section{Population and Sample}

The articles were searched by considering the eligibility criteria which were determined using the PICO model. The population of the study was pregnant women with anemia with a sample of the intervention group and the control group.

\section{Inclusion Criteria}

The inclusion criteria were a full paper article with the randomized controlled trial. Articles were in English or Indonesian. The therapy given was ferric carboxymaltose and iron sucrose as the comparison. The subjects of the study were pregnant women with anemia.

\section{Exclusion Criteria}

The study was conducted with an observational study. The Articles published before 2010.

\section{Operational Definition of Variables}

Hemoglobin levels in pregnant women with anemia were conditions of mothers with $\mathrm{Hb}$ levels below 11 gr\% in the first and third trimesters or $<10.5 \mathrm{gr} \%$ in the second trimester. The study used laboratory examination instruments and a continuous measuring scale. Ferric carboxymaltose therapy was a new iron complex consisting of an iron hydroxide core stabilized by a carbohydrate shell. The study used the instrument of the dose guideline program in the administration of therapy and a continuous measuring scale. Iron sucrose therapy was iron sucrose which stimulated erythropoiesis so it increased iron availability. The study used the instrument of the dose guideline program in the administration of therapy and a continuous measuring scale.

\section{Data Analysis}

The data processing was carried out by ReviewManager (RevMan5.3) by calculating the effect size and heterogeneity to determine which research models were combined and to form the final meta-analysis result.

\section{RESULTS}

The process of searching for the articles was through journal databases, included: Pubmed, DOAJ, Science Direct, Springer Link, Web of Science, Cochrane, Google Scholar, BMJ, BMC, Research Gate, J Stor, Wiley, Clinical Key, J Gate, SAGE, IEEE Xplore, ERIC Institute of Education Science, BASE, SciELO, WorldCat, Microsoft Academic, Index Copernicus, CABI, Cambridge, Nature, Oxford, ProQuest, and BJOG. The keywords used included: "ferric carboxymaltose" AND "iron sucrose" AND "anemia in pregnancy" AND "randomized control trial" OR RCT, "ferric carboxymaltose" AND "iron sucrose" AND "hemoglobin in pregnancy" AND "randomized control trial". The article review process could be seen in the search flow as follows: The initial search process generated 411 articles, after the process of deleting published articles, there were 368 articles with 96 of them were eligible for a full-text review. The full-text articles were included in the exclusion criteria because of the following reasons:

1. Did not use RCT studies 
Nirwana et al./ The Effect of Ferric Carboxymaltose Versus Iron Sucrose on Hemoglobin Levels

2. The Intervention was not Ferric The following is the flow of the review and Carboxymaltose

3. The outcome was not the hemoglobin level in pregnant women with anemia.

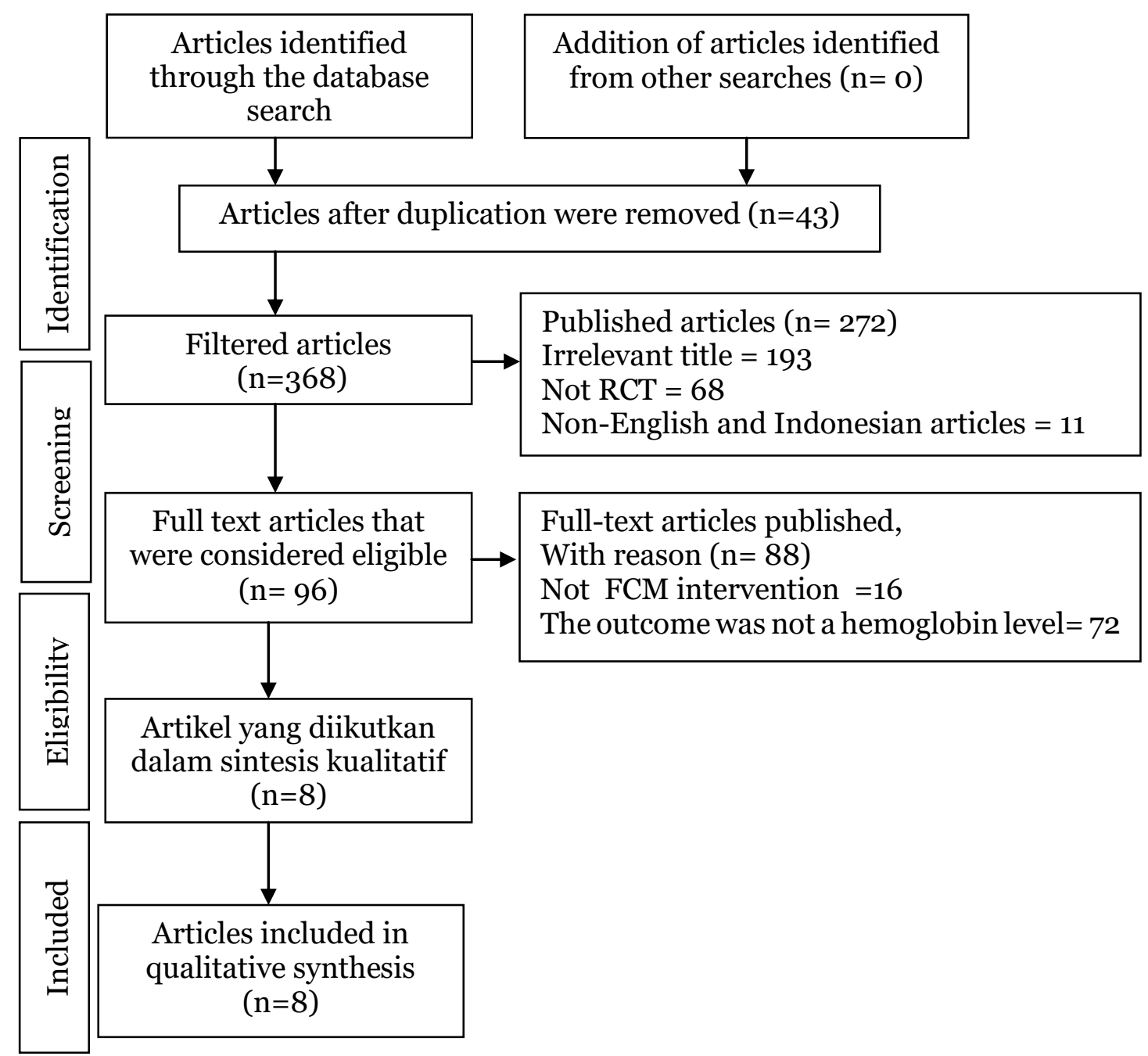

Figure 1. Review Flow Process 
Table 1. The effect of ferric carboxymaltose versus iron sucrose on Hemoglobin Levels in Pregnant Women with Anemia

\begin{tabular}{|c|c|c|c|c|c|c|}
\hline $\begin{array}{l}\text { Author } \\
\text { (years) }\end{array}$ & Title & Country & $\begin{array}{c}\text { Study } \\
\text { Design }\end{array}$ & $\begin{array}{l}\text { Population and } \\
\text { Sample }\end{array}$ & $\begin{array}{c}\text { Intervention } \\
\text { (I) and } \\
\text { comparison (C) }\end{array}$ & Outcome \\
\hline $\begin{array}{l}\text { Jose et al. } \\
\text { (2019) }\end{array}$ & $\begin{array}{l}\text { Comparison of ferric carbo- } \\
\text { xymaltose and iron sucrose } \\
\text { complex for treatment of iron } \\
\text { deficiency anemia in preg- } \\
\text { nancy randomised controlled } \\
\text { trial }\end{array}$ & India & RCT & $\begin{array}{l}\text { The population of } \\
\text { pregnant women with } \\
\text { anemia. The intervention } \\
\text { sample was 50 and the } \\
\text { control sample was 50 }\end{array}$ & $\begin{array}{l}\text { I: Ferric } \\
\text { Carboxymaltose } \\
\text { Therapy } \\
\text { C: Iron Sucrose } \\
\text { Therapy }\end{array}$ & $\begin{array}{l}\text { Hemoglobin levels in the Ferric } \\
\text { Carboxymaltose group were } \\
11.53 \text { gr / dL and hemoglobin } \\
\text { levels in the Iron Sucrose group } \\
\text { were } 10.88 \mathrm{gr} / \mathrm{dL}\end{array}$ \\
\hline $\begin{array}{l}\text { Mahajan et } \\
\text { al. (2018) }\end{array}$ & $\begin{array}{l}\text { A comparative study of effi- } \\
\text { cacy and safety of intrave- } \\
\text { nous ferric carboxymaltose } \\
\text { versus iron sucrose in the } \\
\text { treatment of iron deficiency } \\
\text { anaemia of pregnancy in a } \\
\text { tertiary care hospital }\end{array}$ & India & $\mathrm{RCT}$ & $\begin{array}{l}\text { The Population of preg- } \\
\text { nant women with anemia. } \\
\text { The intervention sample } \\
\text { was } 50 \text { and the control } \\
\text { sample was } 50\end{array}$ & $\begin{array}{l}\text { I: Ferric } \\
\text { Carboxymaltose } \\
\text { Therapy } \\
\text { C: Iron Sucrose } \\
\text { Therapy }\end{array}$ & $\begin{array}{l}\text { Hemoglobin levels in the Ferric } \\
\text { Carboxymaltose group were } \\
10.29 \mathrm{gr} / \mathrm{dL} \text { and hemoglobin } \\
\text { levels in the Iron Sucrose group } \\
\text { were } 9.57 \mathrm{gr} / \mathrm{dL}\end{array}$ \\
\hline $\begin{array}{l}\text { Mahaur et } \\
\text { al. (2020) }\end{array}$ & $\begin{array}{l}\text { Comparative study of iron } \\
\text { sucrose versus ferric carbo- } \\
\text { xymaltose in the manage- } \\
\text { ment of iron deficiency anae- } \\
\text { mia in pregnancy }\end{array}$ & India & RCT & $\begin{array}{l}\text { The population of preg- } \\
\text { nant women with anemia. } \\
\text { The intervention sample } \\
\text { was } 50 \text { and the control } \\
\text { sample was 5o }\end{array}$ & $\begin{array}{l}\text { I: Ferric } \\
\text { Carboxymaltose } \\
\text { Therapy } \\
\text { C: Iron Sucrose } \\
\text { Therapy }\end{array}$ & $\begin{array}{l}\text { Hemoglobin level in the Ferric } \\
\text { Carboxymaltose group was } 10.9 \\
\text { gr / dL and hemoglobin level in } \\
\text { the Iron Sucrose group was } 10.1 \\
\text { gr / dL }\end{array}$ \\
\hline $\begin{array}{l}\text { Maheshwari } \\
\text { et al. (2017) }\end{array}$ & $\begin{array}{l}\text { Evaluation of efficacy, safety } \\
\text { and cost effectiveness of oral } \\
\text { iron and injectable iron } \\
\text { sucrose and ferric carboxy- } \\
\text { maltose in pregnant women } \\
\text { in } 2^{\text {nd }} \text { and } 3^{\text {rd }} \text { trimester in } \\
\text { anaemia }\end{array}$ & India & RCT & $\begin{array}{l}\text { The population of } \\
\text { pregnant women with } \\
\text { anemia. The intervention } \\
\text { sample was } 100 \text { and the } \\
\text { control sample was } 100\end{array}$ & $\begin{array}{l}\text { I: Ferric } \\
\text { Carboxymaltose } \\
\text { Therapy } \\
\text { C: Iron Sucrose } \\
\text { Therapy }\end{array}$ & $\begin{array}{l}\text { Hemoglobin levels in the Ferric } \\
\text { Carboxymaltose group were } \\
11.66 \text { gr / dL and hemoglobin } \\
\text { levels in the Iron Sucrose group } \\
\text { were } 10.4 \mathrm{gr} / \mathrm{dL}\end{array}$ \\
\hline $\begin{array}{l}\text { Naqash et } \\
\text { al. (2018) }\end{array}$ & $\begin{array}{l}\text { Effectiveness and safety of } \\
\text { ferric carboxymaltose } \\
\text { compared to iron sucrose in } \\
\text { women with iron deficiency } \\
\text { anemia }\end{array}$ & India & $\mathrm{RCT}$ & $\begin{array}{l}\text { The population of } \\
\text { pregnant women with } \\
\text { anemia. The intervention } \\
\text { sample was } 50 \text { and the } \\
\text { control sample was 50 }\end{array}$ & $\begin{array}{l}\text { I: Ferric } \\
\text { Carboxymaltose } \\
\text { Therapy } \\
\text { C: Iron Sucrose } \\
\text { Therapy }\end{array}$ & $\begin{array}{l}\text { Hemoglobin levels in the Ferric } \\
\text { Carboxymaltose group were } \\
13.25 \mathrm{gr} / \mathrm{dL} \text { and hemoglobin } \\
\text { levels in the Iron Sucrose group } \\
\text { were } 11.59 \mathrm{gr} / \mathrm{dL}\end{array}$ \\
\hline
\end{tabular}




\begin{tabular}{|c|c|c|c|c|c|c|}
\hline $\begin{array}{l}\text { Neogi et al. } \\
(2019)\end{array}$ & $\begin{array}{l}\text { Safety and effectiveness of } \\
\text { intravenous iron sucrose, } \\
\text { ferric carboxymaltose and } \\
\text { standard oral iron therapy in } \\
\text { pregnant women with } \\
\text { moderate-to-severe anaemia } \\
\text { In India }\end{array}$ & India & $\mathrm{RCT}$ & $\begin{array}{l}\text { The population of } \\
\text { pregnant women with } \\
\text { anemia. The intervention } \\
\text { sample was } 1016 \text { and the } \\
\text { control sample was } 983\end{array}$ & $\begin{array}{l}\text { I: Ferric } \\
\text { Carboxymaltose } \\
\text { Therapy } \\
\text { C: Iron Sucrose } \\
\text { Therapy }\end{array}$ & $\begin{array}{l}\text { Hemoglobin levels in the Ferric } \\
\text { Carboxymaltose group were } 8.1 \\
\text { gr / dL and hemoglobin levels in } \\
\text { the Iron Sucrose group were } 8.1 \\
\text { gr / dL }\end{array}$ \\
\hline $\begin{array}{l}\text { Patel et al. } \\
\text { (2020) }\end{array}$ & $\begin{array}{l}\text { A comparative study of ferric } \\
\text { carboxymaltose and iron } \\
\text { sucrose as a parenteral iron } \\
\text { treatment in iron deficiency } \\
\text { anaemia during pregnancy }\end{array}$ & India & RCT & $\begin{array}{l}\text { The population of } \\
\text { pregnant women with } \\
\text { anemia. The intervention } \\
\text { sample was } 50 \text { and the } \\
\text { control sample was } 50\end{array}$ & $\begin{array}{l}\text { I: Ferric } \\
\text { Carboxymaltose } \\
\text { Therapy } \\
\text { C: Iron Sucrose } \\
\text { Therapy }\end{array}$ & $\begin{array}{l}\text { Hemoglobin levels in the Ferric } \\
\text { Carboxymaltose group were } 11.4 \\
\text { gr / dL and hemoglobin levels in } \\
\text { the Iron Sucrose group were } \\
10.4 \mathrm{gr} / \mathrm{dL}\end{array}$ \\
\hline $\begin{array}{l}\text { Rajwani et } \\
\text { al. (2020) }\end{array}$ & $\begin{array}{l}\text { Randomized clinical trial of } \\
\text { IV iron sucrose and IV ferric } \\
\text { carboxymaltose in the treat- } \\
\text { ment of moderate iron defi- } \\
\text { ciency anaemia in pregnancy. }\end{array}$ & India & $\mathrm{RCT}$ & $\begin{array}{l}\text { The population of } \\
\text { pregnant women with } \\
\text { anemia. 8o intervention } \\
\text { samples and } 80 \text { control } \\
\text { samples }\end{array}$ & $\begin{array}{l}\text { I: Ferric } \\
\text { Carboxymaltose } \\
\text { Therapy } \\
\text { C: Iron Sucrose } \\
\text { Therapy }\end{array}$ & $\begin{array}{l}\text { Hemoglobin levels in the Ferric } \\
\text { Carboxymaltose group were } \\
\text { 10.15 gr / dL and hemoglobin } \\
\text { levels in the Iron Sucrose group } \\
\text { were } 9.88 \mathrm{gr} / \mathrm{dL}\end{array}$ \\
\hline
\end{tabular}


Nirwana et al./ The Effect of Ferric Carboxymaltose Versus Iron Sucrose on Hemoglobin Levels

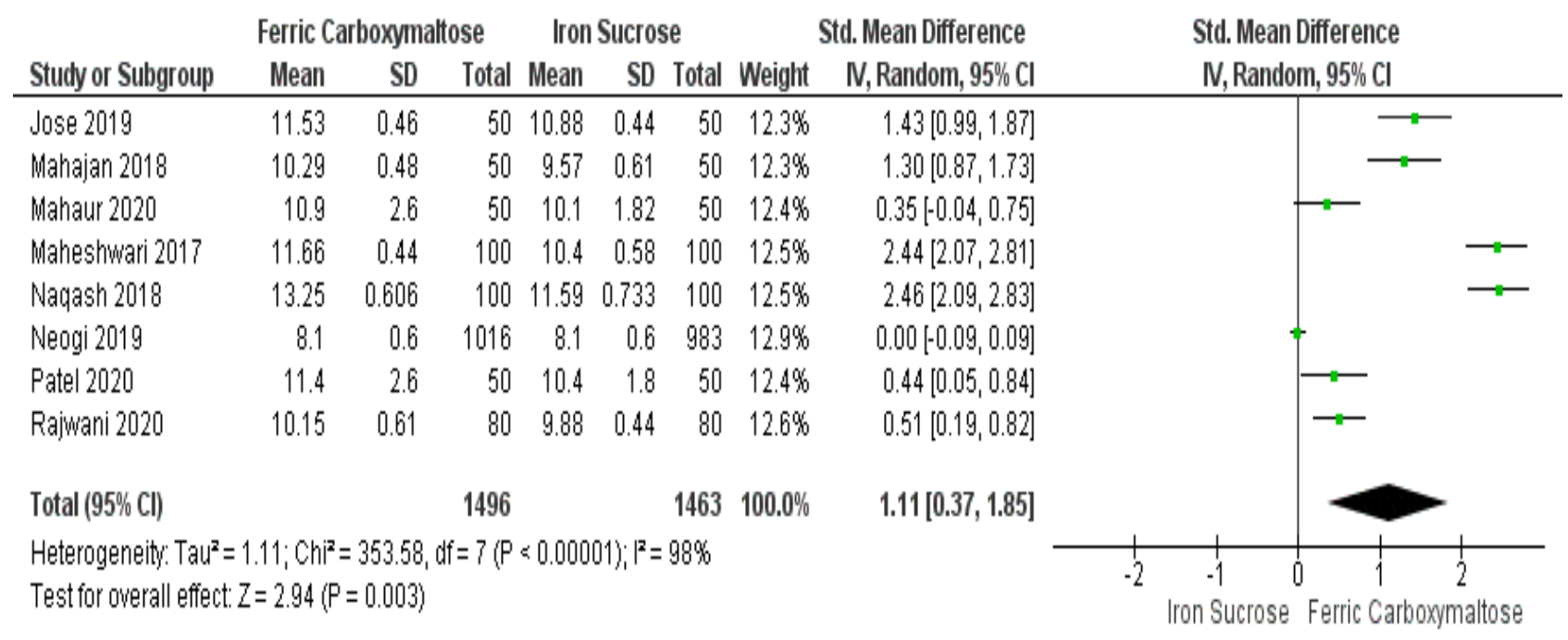

Figure 2. Forest plot of the effect of ferric carboxymaltose versus iron sucrose on hemoglobin levels of pregnant women with anemia

\section{Forest Plot}

The interpretation of the results from the meta-analysis process could be seen through a forest plot. Figure 4.3 showed that pregnant women who were given ferric carboxymaltose therapy had a higher mean hemoglobin level than those who were not

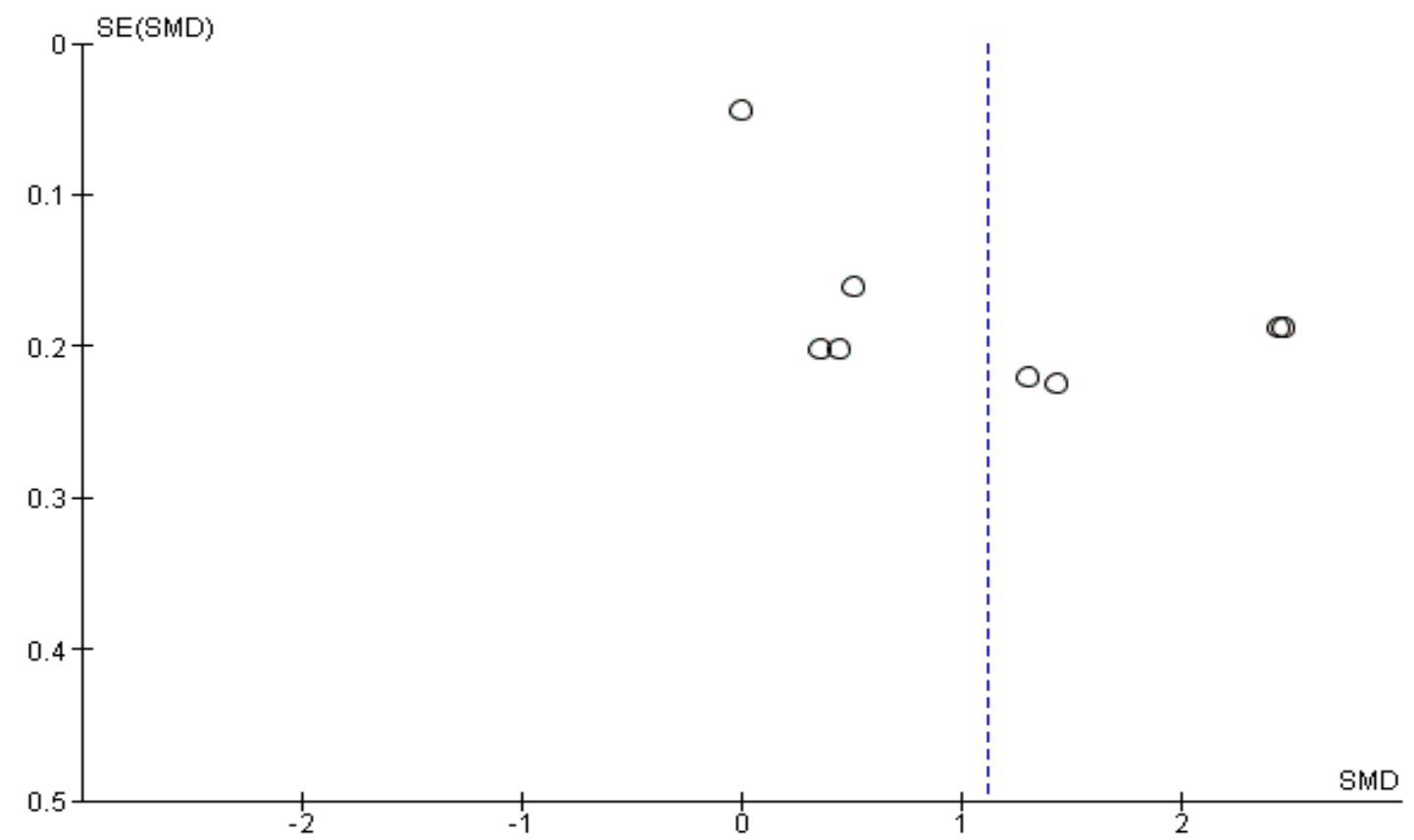

Figure 4. Funnel plot of the effect of ferric carboxymaltose versus iron sucrose on hemoglobin levels in pregnant women with anemia given ferric carboxymaltose therapy and it was statistically significant $(\mathrm{SMD}=1.11 ; 95 \%$ $\mathrm{CI}=0.37$ to $1.85 ; \mathrm{p}=0.003)$. The heterogeneity of the research data showed the result of $\mathrm{I}^{2}=98 \%$ so that the distribution of the data was stated to be heterogeneous (random effect model). 


\section{Funnel Plot}

A funnel plot was a plot that described the estimated effect size of each study on its estimate of accuracy which was usually the standard error.

\section{DISCUSSION}

Anemia is a serious problem for maternal health because anemia is one of the five problems that that becomes the target of solving the World Health Organization (WHO) in 2025. The most common cause of anemia worldwide was iron deficiency anemia which was estimated to be around $50 \%$ of cases (WHO, 2014).

The impact caused by pregnant women who experienced anemia was very diverse and dangerous for both mother and fetus, so it required proper treatment. The mainstay of treatment for iron deficiency anemia was iron supplementation either orally or intravenously. An indication for intravenous iron treatment was intolerance to oral iron. In some countries, intravenous iron preparations such as iron dextran, ferrous sucrose, sodium iron gluconate, and ferric carboximaltose were recommended as alternative treatments for pregnant women who failed to respond to oral therapy (Reveiz, 2012).

Intravenous iron administration as an alternative treatment option for iron deficiency anemia in pregnancy and it had been recommended in various guidelines (Honegger, 2017). The data from observational studies on the efficacy and safety of these new treatments were essential to guide clinical management decisions, and to ensure the safety of pregnant women and their unborn fetuses (Christop, 2010).

Based on the result, this systematic and meta-analysis study raised the theme of the effect of ferric carboxymaltose versus iron sucrose on hemoglobin levels in pregnant women with anemia. The independent variables analyzed were ferric carboxymaltose and iron sucrose. The study that discussed data on hemoglobin levels in pregnant women with anemia was considered important because of the small number of relevant studies published and accessible, and the data access problem (data duplication) (Murti, 2018).

The estimation of the effect of ferric carboxymaltose versus iron sucrose on hemoglobin levels in pregnant women with anemia was processed using the RevMan 5.3 application with the continuous method. This method was used if the outcome was continuous data.

The results of the systematic study and meta-analysis were presented in the form of a forest plot and a funnel plot. Forest plots showed visually the large variation in heterogeneity (Akobeng, 2005 in Murti, 2018). The funnel plot presented the relationship between the effect size of the study and the sample size of the various studies researched, which could be measured in some different ways (Murti, 2018). Funnel plots could be assessed from the asymmetry of the study, which included the number of dots on the right and left sides compared to the standard error and the balance of the number of studies on the right and left (D'Souza et al, 2002).

The results of the forest plot ferric carboxymaltose versus iron sucrose on hemoglobin levels in pregnant women with anemia showed that pregnant women who were given ferric carboxymaltose therapy had a higher mean hemoglobin level than those who were not treated with ferric carboxymaltose and it was statistically significant $(\mathrm{SM}=1.11 ; 95 \%$ $\mathrm{CI}=0.37$ to $1.85 ; \mathrm{p}=0.003$ ).

A study conducted by Naqash et al., (2018) aimed to evaluate the effectiveness and safety of Ferric Carboxymaltose compared to Iron Sucrose in pregnant women with anemia. The study stated that hemoglobin at week 4 was recorded as mean $=13.25$ and $\mathrm{SD}=0.606$ in the Ferric Carboxymaltose 
Nirwana et al./ The Effect of Ferric Carboxymaltose Versus Iron Sucrose on Hemoglobin Levels

group. However, in the Iron Sucrose group the mean $=11.59$ and $\mathrm{SD}=0.733$ with $(\mathrm{p}$ $<0.001)$. It proved that Ferric Carboxymaltose was better than Iron Sucrose in the management of anemia in pregnant women. Ferric Carboxymaltose and Iron Sucrose also showed an increase in ferritin levels, in that study Ferric Carboxymaltose showed a significant increase in ferritin levels. The detailed mean value of other laboratory parameters proved that Ferric Carboxymaltose was a better therapy for the management of anemia in pregnant women compared to Iron Sucrose. Based on observations from various research results, it is reasonable to state that Ferric Carboxymaltose is more effective than Iron Sucrose in the management of iron deficiency anemia in pregnant women.

\section{AUTHOR CONTRIBUTION}

Astika Candra Nirwana was the main researcher who selected the topics, explored, and collected the data. Yulia Lanti Retno Dewi and Bhisma Murti had a role in analyzing data and reviewing documents.

\section{CONFLICT OF INTEREST}

There was no conflict of interest in this study.

\section{FUNDING AND SPONSORSHIP}

This study used personal funds from the main researcher.

\section{REFERENCE}

Bekele A, Tilahun M, Mekuria A (2016). Prevalence of anemia and its associated factors among pregnant women attending antenatal care in Health Institutions of Arba Minch Town, Gamo Gofa Zone, Ethiopia: A CrossSectional Study. Anemia. 2016: 1073192. https://doi.org/10.1155/2016/1073192.

Bilimale A, Anjum J, Sangolli HN, Mallapur M (2010). Improving adherence to oral iron supplementation during pregnan- cy. Maternal Health, Nutrition, Anaemia. 3(5): 281-290. https://doi.org/10.4066/AMJ.2010.291

Camaschella C (2015). Iron-deficiency anemia. New England Journal of Medicine.372(19): 1832-1843. https://doi.org/10.10- 56/nejmra1401038

Christoph P, Schuller C, Studer H, Irion O, De Tejada BM, Surbek D (2012). Intravenous iron treatment in pregnancy: Comparison of high-dose ferric carboxymaltose vs. iron sucrose. Journal of Perinatal Medicine, 40(5): 469-474. https://doi.org/10.1515/jpm-2011-0231

Gogoi I, Mahanta TG, Sarma PR, Gogoi PP, Saikia H (2016). Prevalence and sociodemographic factors affecting anaemia in pregnant women of Dibrugarh district, Assam, India. Indian Journal of Community Health, 28(2): 202-207.

Jose A, Mahey R, Sharma JB, Bhatla N, Saxena R, Kalaivani M, Kriplani A (2019). Comparison of ferric carboxymaltose and iron sucrose complex for treatment of iron deficiency anemia in pregnancy-randomised controlled trial. BMC Pregnancy and Childbirth, 19(1): 1-8. https://doi.org/10.1186/s12884019-2200-3.

Khaskheli M, Baloch S, Baloch AS, Baloch S, Khaskheli FK (2016). Iron deficiency anaemia is still a major killer of pregnant women. Pakistan Journal of Medical Sciences. 32(3): 630-634. https://doi.org/10.12669/pjms.323.9557.

Mahajan AR, Bhagat B, Gupta S, Mahajan B, Verma $M$ (2018). A comparative study of efficacy and safety of intravenous ferric carboxymaltose versus iron sucrose in the treatment of iron deficiency anaemia of pregnancy in a tertiary care hospital. International Journal of Reproduction, Contraception, Obstetrics and Gynecology, 7(5): 1938. https://- 
Nirwana et al./ The Effect of Ferric Carboxymaltose Versus Iron Sucrose on Hemoglobin Levels

dx.doi.org/10.18203/2320-1770.ijrcog20181933.

Murti B (2018). Prinsip dan metode riset epidemiologi. Edisi IV. Surakarta: Bintang Fajar Offset.

Naqash A, Ara R, Bader GN (2018). Effectiveness and safety of ferric carboxymaltose compared to iron sucrose in women with iron deficiency anemia: phase IV clinical trials. BMC Women's Health, 18(1): 6. https://doi.org/10.1186/s12905-017-0506-8.

Neogi SB, Devasenapathy N, Singh R, Bhushan H, Shah D, Divakar H, Baswal D (2019). Safety and effectiveness of intravenous iron sucrose versus standard oral iron therapy in pregnant women with moderate-to-severe anaemia in India: a multicentre, open-label, phase 3 , randomized, controlled trial. The Lancet Global Health, 7(12): e1706-e1716. https://doi.org/10.1016/S2214-109X(19)30427-9.

Patel R, Delivala K, Bhatt S (2019). Parenteral iron treatment in pregnancy: comparision of high-dose ferric carboxymaltose vs. iron sucrose. 8(9): 4649. https://www.worldwidejournals.com/international-journal-of-scientific-research-(IJSR)/article/parenteraliron-treatment-in-pregnancy-comparision-of-high-dose-ferric-carboxymal-
tose-vs-iron-sucrose/MjE4ODU=/?is=$1 \& \mathrm{~b} 1=405 \& \mathrm{k}=102$.

Pavord S, Myers B, Robinson S, Allard S, Strong J, Oppenheimer C (2012). UK guidelines on the management of iron deficiency in pregnancy. British Journal of Haematology. 156(5): 588-600. https://doi.org/10.1111/bjh.16221.

Qassim A, Mol, BW, Grivell RM, Grzeskowiak LE (2018). Safety and efficacy of intravenous iron polymaltose, iron sucrose and ferric carboxymaltose in pregnancy: A systematic review. Australian and New Zealand Journal of Obstetrics and Gynaecology, 58(1): 2239. https://doi.org/10.1111/ajo.12695.

Rahman MM, Abe SK, Rahman MS, Kanda M, Narita S, Bilano V, Ota E, et al (2016). Maternal anemia and risk of adverse birth and health outcomes in low and middle-income countries: systematic review and meta-analysis. Am J Clin Nutr. 103(02): 495-504. https://doi.org/10.3945/ajcn.115.107896.

Reveiz L, Gyte GM, Cuervo LG, Casasbuenas A (2011). Treatments for iron deficiency anaemia in pregnancy. Cochrane Database of Systematic Reviews. (2): CDo03094. https://doi.org/10.1002/14651858.cdoo3- 094.pub3.

World Health Organization. (2014). World Health Statistic. Geneva: WHO. 